\title{
Bibliography
}

\section{Archival sources}

\section{Greater Manchester County Record Office}

GB127/M6/1/15.

Royal Manchester Institution, Reconstruction Committee Minutes, 1943-45. GB127/M723/26.

Ancoats Clearance Area File (1652), 1930-43.

GB127/M723/61.

City Engineer's Department, Newspaper Cuttings, January 1938 - June 1945. GB127/M740/2/8/3/53.

New Estates Federation of Manchester and District Meetings, 1935.

GB127/Council Minutes/Emergency Committee.

Emergency Committee, vol. 3, 1 July 1931 - October 1940.

Emergency Committee, vol. 4, 7 November 1940 - 30 January 1941.

GB127/Council Minutes/Housing Committee.

Housing Committee, vol. 23, 20 July 1939 - 11 November 1940.

Housing Committee, vol. 25, 8 February 1943 - 26 July 1944.

Housing Committee, vol. 26, 14 August 1944 - 25 June 1945.

Housing Committee, vol. 27, 9 July 1945 - 2 April 1946.

Housing Committee, vol. 28, 8 April 1946 - 23 December 1946.

Housing Committee, vol. 29, 13 January 1947 - 13 October 1947.

Housing Committee, vol. 30, 17 November 1947 - 28 July 1948.

Housing Committee, vol. 38, 13 April 1953 - 23 December 1953.

GB127/Council Minutes/Post-war Reconstruction Committee.

Post-war Reconstruction Committee, 1942-48.

GB127/Council Minutes/Manchester and District Regional Planning Committee.

Manchester and District Regional Planning Committee, May 1945 - May 1948.

GB127/Council Minutes/Wythenshawe Estate Special Committee.

Wythenshawe Estate Special Committee, vol. 6, 13 July 1938 - 18 October 1939.

Wythenshawe Estate Special Committee, vol. 7, 15 November 1939 - 21 January 1942. 
Wythenshawe Estate Special Committee, vol. 8, 25 February 1942 - 23 January 1945.

Wythenshawe Estate Special Committee, vol. 9, 27 Feb 1945 - 27 Aug 1946. Wythenshawe Estate Special Committee, vol. 10, 24 September 1946 - 3 December 1947.

Wythenshawe Estate Special Committee, vol. 11, 2 January 1948 - 22 April 1949.

Wythenshawe Estate Special Committee, vol. 12, 27 May 1949 - 1 September 1950.

Wythenshawe Estate Special Committee, vol. 13, 6 October 1950 - 2 February 1951.

\section{Hansard}

House of Commons Debate, vol. 336, col. 1392 (26 May 1938).

House of Commons Debate, vol. 362, cols 51-64 (18 June 1940).

House of Lords Debate, vol. 129, no. 91, col. 89 (22 September 1943).

House of Commons Debate, vol. 545, col. 1389 (3 November 1955).

\section{Hull History Centre}

CTAY, Records relating to the repair of war damaged property and other wartime functions.

CTAY, Air raid reports, 1939-45.

CTAH/2, Records of the Housing Section.

Box 2187, File 64.

Box 2173, File 100.

Box 2193, File 36.

Box 2020, Files $24 \& 203$.

CTAH/5, Miscellaneous Records of the Housing Section.

M22, Houses - Location.

M31, The Plan.

CTAH/6.3, Temporary Estates, Notes and Correspondence from Tenants, $1946-49$.

FG4, Fencing of Temporary Accommodation.

FG5/1, Tenants' Complaints, 1946-1948.

FG5/2, Complaints Concerning Gardens, 1948-1949.

FG10, Complaints Concerning Cattle Ingres.

CTCR, Housing and Town Planning Section.

Housing and Town Planning Section 1.8.9.

Housing and Town Planning Section 1.12.5.

Housing and Town Planning Section 1.14.5.

Housing and Town Planning Section 1.16.6.

Housing and Town Planning Section 1.19.8.

Imperial War Museum, London

IWM/PST/2909, 29010 \& 2911. 


\section{Mass Observation Archive, University of Sussex}

FR538, Report on Manchester and Liverpool, 6 January 1941.

FR1616, Some Psychological Factors in Home Building, 3 March 1943.

\section{National Archives, Kew}

HLG/71, Ministry of Town and Country Planning and predecessors and successors: Planning Policy and Statutory Planning Functions, Registered Files HLG/71/410, Provisions for camping and travelling fairs, 1947-48. HLG/71/1027, Billposting and advertising industry: representations, 1942-43. HLG/71/1062, Meetings and discussions on advertisement control generally, 1949-51.

HLG/71/1138, Town and country planning amendment regulations 1945, 1944-1945.

HLG/71/1738, Appeals policy [Advertisements], 1947-57.

HLG/79, Ministry of Town and Country Planning and Successors: Local Authority Plans and Development Proposals, Registered Files.

HLG/79/256, War damage redevelopment: town planning and reconstruction, 1942-49.

HLG/79/257, Development plan: correspondence prior to submission, 1951. HLG/79/261, Re-planning of borough: general, 1944-48.

HLG/79/262, Re-planning and reconstruction: railways - level crossings, $1944-46$.

HLG/79/268, Redevelopment proposals: shopping area, 1947-48.

HLG/79/269, Replanning discussions: deputation to Minister, 1947.

HLG/79/402, Weekend Conference at Manchester University on 14 and 15

November 1942 on Replanning and Reconstruction of the Large Towns, 1942-47.

HLG/79/405, War damage redevelopment: general, 1944-47.

HLG/79/407, War damage redevelopment: market place, 1946-50.

HLG/79/421, Advertisements: Moss Lane West: appeal by Arthur Maiden Limited, 1948-49.

HLG/79/422, Advertisements: Stockport Road: appeal by More O'Ferrall Limited, 1949.

HLG/79/424, War damage redevelopment: proposals, 1941-49.

HLG/79/1723, Notes on the 1948 Restrictions on Advertising.

HLG/88/8, Ministry of Town and Country Planning: Advisory Committee on

Estate Development

\section{Newspapers}

Advertisers' Weekly

Daily Mirror

Hull Daily Mail

Manchester Evening Chronicle

Manchester Evening News

Manchester Guardian 
The Observer

The Times

World's Press News and Advertisers' Review

\section{Parliamentary and government papers}

Housing, Town Planning, \&c Act 1909.

Town and Country Planning Act 1932.

Public Health Act 1936.

Town and Country Planning Act 1944.

Town and Country Planning Act 1947 (also 1948 addition).

HMSO, Town and Country Planning, 1943-1951, Progress Report, Cmd 8204 (London, 1951).

\section{Thomas Fischer Rare Book Library, Toronto}

'Hull', Plate 984, c.1642.

University of Manchester Library (Special Collections)

EPL49, A Plan of Manchester \& Salford c.1650. Drawn from a Plan in the Possession of William Yates Esqr. by John Palmer1822.

\section{Online archives and sources}

A City Speaks, film, directed by Paul Rotha (United Kingdom, 1947), http:// player.bfi.org.uk/film/watch-city-speaks-1947/, accessed 16 September 2016.

'Archive maps pinpoint Manchester Blitz bomb sites', 14 December 2012, Manchester Evening News, http://menmedia.co.uk/manchestereveningnews/news/s/1596191_archive-maps-pinpoint-manchester-blitz-bomb-sites, accessed 9 January 2016.

Clear Channel Group, 'Our history', www.clearchannel.co.uk/who-we-are/ history, accessed 12 August 2016.

'From the archive, 30 December 1940', The Guardian, 30 December 2010, www.theguardian.com/theguardian/2010/dec/30/london-blitzed-by-germanbombers, accessed 19 May 2016.

'Listed status for bombed cinema', BBC News, 2 February 2007, http://news. bbc.co.uk/1/hi/england/humber/6324301.stm, accessed 12 December 2016.

Manchester City Council, 'Air quality', www.manchester.gov.uk/info/413/pollu tion_control-air_quality/2942/air_quality/6, accessed 19 April 2016.

'More O'Ferrall profits soar: poster advertising group ahead "in difficult conditions"', The Independent, 24 March 1994, www.independent.co.uk/ news/business/more-oferrall-profits-soar-poster-advertising- group-ahead-indifficult-conditions-1431281.html, accessed 1 June 2016.

Office of Government Statistics, 'House building completions: social trends 32', www.statistics.gov.uk/StatBase/ssdataset.asp? vlnk=5118\&Pos=2\&ColRank $=2 \&$ Rank=448, accessed 14 January 2016.

Prince of Wales, 'Speech by HRH The Prince of Wales, 150th anniversary of the Royal Institute of British Architects (RIBA), Royal Gala Evening at 
Hampton Court Palace', 30 May 1984, www.princeofwales.gov.uk/media/ speeches/speech-hrh-the-prince-of-wales-the-150th-anniversary-of-the-royalinstitute-of, accessed 19 September 2016.

The Scottish Office, 'Investing in modernisation: an agenda for Scotland's housing', www.scotland.gov.uk/library/documents-w7/hgp-04.html, accessed 12 January 2016.

'Secret plan to demolish Manchester town hall revealed', BBC News, 5 October 2013, www.bbc.co.uk/news/uk-england-manchester-24330693, accessed 15 September 2016.

Thatcher, Margaret, 'Conservative Party Conference Speech', 9 October 1987, www.margaretthatcher.org/document/106941, accessed 20 September 2016.

\section{Printed primary sources}

Abercrombie, Patrick, and John Henry Forshaw. County of London Plan (London, 1943).

City Council of Kingston upon Hull. Planning in Action: An Account of the Aims and Achievements in Kingston upon Hull (Hull, 1958).

Hall, M.P. Community Centres and Associations in Manchester: A Survey made in 1945 by the Manchester and Salford Council of Social Service (Manchester, 1946).

Lock, Max. Civic Diagnosis: A Blitzed City Analysed [an outline summary of research undertaken by the Hull Regional Survey] (London, 1943).

Lutyens, Edwin, and Patrick Abercrombie. A Plan for the City and County of Kingston upon Hull (Hull, 1945).

Manchester and District Joint Town Planning Advisory Committee. Report upon the Regional Scheme (Manchester, 1926).

Ministry of Education. Community Centres (London, 1944).

Ministry of Health. Design of Dwellings (London, 1944).

Ministry of Health/Ministry of Works. Housing Manual 1944 (London, 1944).

Ministry of Health/Ministry of Works. Temporary Accommodation: Memorandum for the Guidance of Local Authorities (London, 1944).

National Council of Social Services. The Size and Social Structure of a Town (London, 1943).

Nicholas, Rowland. City of Manchester Plan (Norwich, 1945).

Nicholas, Rowland. City of Manchester Plan: Abridged Edition (Norwich, 1945).

Nicholas, Rowland. The Manchester and District Regional Planning Committee: Report on the Tentative Regional Planning Proposals (Norwich, 1945).

Nicholas, Rowland, and M.J. Hellier. South Lancashire and North Cheshire Advisory Planning Committee: Advisory Plan 1947 (Manchester, 1947).

Retailers' Advisory Committee on Town Planning. The Planning of Shopping Areas: Setting out the Principles which should be followed in Planning Shopping Areas (London, 1944). 


\section{Secondary material}

Adams, David. 'Everyday experiences of the modern city: remembering the post-war reconstruction of Birmingham', Planning Perspectives, 26:2 (2011), 237-60.

Addison, Paul. The Road to 1945: British Politics and the Second World War (London, 1975).

Alexander, Ernest, and Andreas Faludi. 'Planning and plan implementation: notes on evaluation criteria', Environment and Planning B: Planning and Design, 16:2 (1989), 127-40.

Alexander, Andrew. 'Retailing and consumption: evidence from war time Britain', International Review of Retail, Distribution and Consumer Research, 12:1 (2002), 39-57.

Amery, Colin, and Dan Cruickshank. The Rape of Britain (London, 1975).

Aminzade, Ronald, Jack Goldstone, Doug McAdam, Elizabeth Perry, William Sewell, Sidney Tarrow, and Charles Tilly (eds). Silence and Voice in the Study of Contentious Politics (Cambridge, 2001).

Anderson, Ben. 'A liberal countryside? The Manchester Ramblers' Federation and the "social readjustment" of urban citizens, 1929-1936', Urban History, 38:1 (2011), 84-102.

Arnason, Johann P. 'Communism and modernity', Daedalus, 129:1 (2000), 61-90.

Augé, Marc. Non-Places: Introduction to an Anthropology of Supermodernity (London, 2008).

Baker, Laura. 'Public sites versus public sights: the progressive response to outdoor advertising and the commercialization of public space', American Quarterly, 59:4 (2007), 1187-213.

Barker, Ernest. New Housing Estates and their Social Problems (London, 1935).

Barnett, Correlli. The Audit of War: The Illusion and Reality of Britain as a Great Nation (London, 1986).

Bauman, Zygmunt. Modernity and Ambivalence (Cambridge, 1991).

Bauman, Zygmunt. Postmodern Ethics (Oxford, 1993).

Bauman, Zygmunt. Modernity and the Holocaust (Cambridge, 2000).

Bauman, Zygmunt. Liquid Modernity (Cambridge, 2000).

Beaven, Brad, and John Griffiths. 'Creating the exemplary citizen: the changing notion of citizenship in Britain 1870-1939', Contemporary British History, 22:2 (2008), 203-25.

Beaven, Brad, and David Thoms. 'The Blitz and civilian morale in three northern cities', Northern History, 32:1 (1996), 195-203.

Beck, Arthur Peter. 'Housing in England and Wales during the business depression of the 1930s', Economic History Review, 3:3 (1951), 321-41.

Benjamin, Walter. The Arcades Project, trans. Rolf Tiedemann (London, 1999).

Benson, John. The Rise of Consumer Society in Britain, 1880-1980 (London, 1994). 
Berman, Marshall. All That Is Solid Melts into Air: The Experience of Modernity (London, 1983).

Biddle, Tami Davis. 'British and American approaches to strategic bombing: their origins and implementation in the World War II combined bomber offensive', Journal of Strategic Studies, 18:1 (1995), 91-144.

Blanco White, Margaret Justin. 'Manchester [district] planning scheme, by R. Nicholas', Architects’ Journal, 6 September (1945), 169-72.

Booth, Philip. 'Discretion in planning versus zoning', in Barry Cullingworth (ed.), British Planning: 50 Years of Urban and Regional Policy (London, 1999).

Bourke, Joanna. Working-class Cultures in Britain, 1890-1960: Gender, Class and Ethnicity (London, 1994).

Brenner, Neil. 'The limits to scale? Methodological reflections on scalar structuration', Progress in Human Geography, 25:4 (2001), 591-614.

Bromley, Rosemary, and Colin Thomas (eds). Retail Change: Contemporary Issues (London, 1993).

Buchanan, Peter. 'What city? A plea for place in the public realm', Architectural Review, 1101 (1988), 31-41.

Bullock, Nicholas. 'Plans for post-war housing in the UK: the case for mixed development and the flat', Planning Perspectives, 2:1 (1987), 71-98.

Bullock, Nicholas. 'Ideals, priorities and harsh realities: reconstruction and the LCC, 1945-51', Planning Perspectives, 9:1 (1994), 87-101.

Bullock, Nicholas. Building the Post-war World: Modern Architecture and Reconstruction in Britain (London, 2002).

Burnett, John. A Social History of Housing, 1815-1970 (London, 1978).

Burns, Wilfred. New Towns for Old: The Technique of Urban Renewal (London, 1963).

Button, John (ed.). Look Here! Considering the Australian Environment (Melbourne, 1968).

Calder, Angus. The Myth of the Blitz (London, 1992).

Calkins, Hugh. 'The planning monitor: an accountability theory of plan evaluation', Environment and Planning A, 11:7 (1979), 745-58.

Calvert, Hugh. A History of Kingston upon Hull: From the Earliest Times to the Present Day (London, 1978).

Cardwell, Donald S.L. (ed.). Artisan to Graduate: Essays to Commemorate the Foundation in 1824 of the Manchester Mechanics' Institution (Manchester, 1974).

Caruana, Viv, and Colin Simmons. 'The development of Manchester Airport, 1938-1978: central government subsidy and local authority management', Journal of Transport Geography, 9:4 (2001), 279-92.

Certeau, Michel de. The Practice of Everyday Life (London, 1984).

Cherry, Gordon. The Evolution of British Town Planning: A History of Town Planning in the United Kingdom During the 20th Century and of the Royal Town Planning Institute, 1914-74 (Leighton Buzzard, 1974).

Cherry, Gordon. The Politics of Town Planning (London, 1982). 
Cherry, Gordon. Cities and Plans: The Shaping of Urban Britain in the Nineteenth and Twentieth Centuries (London, 1988).

Cherry, Gordon. Birmingham: A Study in Geography, History and Planning (Chichester, 1994).

Clapson, Mark. Invincible Green Suburbs, Brave New Towns: Social Change and Urban Dispersal in Post-war England (Manchester, 1998).

Clapson, Mark, and Peter J. Larkham (eds). The Blitz and its Legacy: Wartime Destruction to Post-war Reconstruction (Farnham, 2013).

Clark, William, and Gerard Rushton. 'Models of intra-urban consumer behaviour and their implications for central place theory', Economic Geography, 46:3 (1970), 486-97.

Clarke, Raymond T. (ed.). Enterprising Neighbours: The Development of the Community Association Movement in Britain (London, 1990).

Cleveland, S.D. The Royal Manchester Institution (Manchester, 1931).

Cloke, Paul, and Owain Jones. 'Unclaimed territory: childhood and disordered space(s)', Social \& Cultural Geography, 6:3 (2005), 311-33.

Cohen, Anthony P. The Symbolic Construction of Community (Chichester, 1985).

Coleman, Alice. Utopia on Trial: Vision and Reality in Planned Housing (London, 1985).

Collison, Peter. 'Town planning and the neighbourhood unit concept', Public Administration, 32:4 (1954), 463-69.

Colls, Robert, and Richard Rodger (eds). Cities of Ideas: Civil Society and Urban Governance in Britain 1800-2000 (Aldershot, 2004).

Conekin, Becky, Frank Mort, and Chris Waters (eds). Moments of Modernity: Reconstructing Britain 1945-1964 (London, 1999).

Conway, Hazel. 'Everyday landscapes: public parks from 1930 to 2000', Garden History, 28:1 (2000), 117-34.

Cosgrove, Denis (ed.). Mappings (London, 1999).

Cosgrove, Denis, and Stephen Daniels (eds). The Iconography of Landscape (Cambridge, 1988).

Crang, Mike, and Nigel Thrift (eds). Thinking Space (Abingdon, 2000).

Cresswell, Tim. In Place/Out of Place: Geography, Ideology, and Transgression (Minneapolis, 1996).

Cresswell, Tim. Place: A Short Introduction (Oxford, 2004).

Cullingworth, Barry.Environmental Planning, 1939-1969. Vol.1, Reconstruction and Land Use Planning, 1939-1947 (London, 1975).

Cullingworth, Barry, and Vincent Nadin (eds). Town and Country Planning in the UK (London, 2002).

Darling, Elizabeth. Re-forming Britain: Narratives of Modernity before Reconstruction (Abingdon, 2007).

Daunton, Martin (ed.). The Cambridge Urban History of Britain. Vol. 3, 18401950 (Cambridge, 2000).

Daunton, Martin, and Bernard Rieger (eds). Meanings of Modernity: Britain from the Late-Victorian Era to World War II (Oxford, 2001). 
David-Fox, Michael. 'Whither resistance?', Kritika, 1:1 (2000), 161-5.

Davies, Andrew. Leisure, Gender and Poverty: Working-class Culture in Salford and Manchester, 1900-1939 (Buckingham, 1992).

Davies, Andrew. The Gangs of Manchester (Preston, 2009).

Davies, Andrew, and Steven Fielding (eds). Workers' Worlds: Cultures and Communities in Manchester and Salford, 1880-1939 (Manchester, 1992).

Davis, John. Youth and the Condition of Britain: Images of Adolescent Conflict (London, 1990).

Davoudi, Simin. 'Sustainability: a new vision for the British planning system', Planning Perspectives, 15:2 (2000), 123-7.

Day, R.A. 'Consumer shopping behaviour in a planned urban environment', Tijdschrift voor Economische en Sociale Geografie, 64:2 (1973), 77-85.

Deakin, Derick. Wythenshawe: The Story of a Garden City (Chichester, 1989).

Debord, Guy. Society of the Spectacle (Detroit, 1970).

Delle, James A. An Archaeology of Social Space: Analyzing Coffee Plantations in Jamaica's Blue Mountains (London, 1998).

Dougill, Wesley. 'Urban improvement schemes: II. Ferensway, Hull', Town Planning Review, 16:2 (1934), 123-5.

Dougill, Wesley. 'Wythenshawe: a modern satellite town', Town Planning Review, 16:3 (1935), 209-15.

Douglas, Ian, Rob Hodgson, and Nigel Lawson. 'Industry, environment and health through 200 years in Manchester', Ecological Economics, 41:2 (2002), 235-55.

Dunleavy, Patrick. The Politics of Mass Housing in Britain 1945-1975 (Oxford, 1981).

Edgerton, David. Warfare State: Britain 1920-1970 (Cambridge, 2006).

Eisenstadt, Schmuel N. 'Multiple modernities', Daedalus, 129:1 (2000), 1-29.

Esher, Lionel. A Broken Wave: The Rebuilding of England 1940-1980 (London, 1981).

Essex, Stephen, and Mark Brayshay. 'Vision, vested interest and pragmatism: who re-made Britain's blitzed cities?', Planning Perspectives, 22:4 (2007), 417-41.

Essex, Stephen, and Mark Brayshay. 'Boldness diminished? The post-war battle to replan a bomb damaged city', Urban History, 35:3 (2008), 437-61.

Fielding, Steven. 'What did the people want? The meaning of the 1945 general election', Historical Journal, 35 (1992), 623-39.

Fielding, Steven, Peter Thompson, and Nick Tiratsoo. 'England Arise!': The Labour Party and Popular Politics in 1940s Britain (Manchester, 1995).

Fishman, Robert. The American Planning Tradition: Culture and Policy (Washington, 2000).

Flinn, Catherine. "The city of our dreams"? The political and economic realities of rebuilding Britain's blitzed cities, 1945-54', Twentieth Century British History, 23:2 (2012), 221-45.

Foley, Donald L. 'British town planning: one ideology or three?', British Journal of Sociology, 11:3 (1960), 211-31. 
Foley, Donald L. Controlling London's Growth: Planning the Great Wen, 1940-1960 (Berkeley, 1963).

Forster, Clive A. Court Housing in Kingston upon Hull: An Example of Cyclic Processes in the Morphological Development of Nineteenth-century Bye-law Housing (Hull, 1972).

Foucault, Michel. The Birth of the Clinic: An Archaeology of Medical Perception (London, 1973).

Foucault, Michel. 'Governmentality', Ideology and Consciousness, 6 (1979), 5-21.

Foucault, Michel. Power/Knowledge: Selected Interviews and Other Writings, 1972-1977, Colin Gordon (ed.) (Brighton, 1980).

Frankenberg, Ronald. Communities in Britain: Social Life in Town and Country (Harmondsworth, 1969).

Franzén, Mats. 'Urban order and the preventive restructuring of space: the operation of border controls in micro space', Sociological Review, 49:2 (2001), 202-18.

Fyfe, Nicholas (ed.). Images of the Street: Planning, Identity and Control in Public Space (London, 1998).

Gans, Herbert. The Urban Villagers (New York, 1962).

Garreau, Joel. Edge City: Life on the New Frontier (New York, 1991).

Gennep, Arnold van. The Rites of Passage (London, 1960).

Geraghty, Tom. North East Coast Town. Ordeal \& Triumph: The Story of Kingston-upon-Hull in the 1939-1945 Great War (Hull, 2002).

Giddens, Anthony. The Consequences of Modernity (Cambridge, 1990).

Giddens, Anthony. Modernity and Self-identity: Self and Society in the Late Modern Age (Cambridge, 1991).

Gieryn, Thomas F. 'A space for place in sociology', Annual Review of Sociology, 26:1 (2000), 463-96.

Gilbert, David. 'London of the future: the metropolis reimagined after the Great War', Journal of British Studies, 43:1 (2004), 91-119.

Gilbert, David, David Matless, and Brian Short (eds). Geographies of British Modernity: Space and Society in the Twentieth Century (Oxford, 2003).

Giles, Judy. Women, Identity and Private Life in Britain, 1900-50 (Basingstoke, 1995).

Gill, Crispin. Plymouth: A New History (Tiverton, 1993).

Gillett, Edward, and Kenneth A. MacMahon. A History of Hull (Oxford, 1980).

Gillis, John R. 'The evolution of juvenile delinquency in England 1890-1914', Past \& Present, 67:1 (1975), 96-126.

Glass, Ruth. The Social Background of a Plan: A Study of Middlesbrough (London, 1948).

Glass, Ruth, and L.E. White. 'A warning to planners: the story of the Honor Oak estate', National House Builder and the Building Digest, September (1945), 25-9. 
Glendinning, Miles, and Stefan Muthesius. Tower Block: Modern Public Housing in England, Scotland, Wales, and Northern Ireland (New Haven, CT, 1994).

Glinert, Ed. The Manchester Compendium: A Street-by-Street Guide to England's Greatest Industrial City (London, 2008).

Gold, John. 'The MARS Plan for London, 1933-1942: plurality and experimentation in the city plans of the early British modern movement', Town Planning Review, 66:3 (1995), 243-67.

Gold, John. The Experience of Modernism: Modern Architects and the Future City, 1928-1953 (London, 1997).

Gold, John. The Practice of Modernism: Modern Architects and Urban Transformation, 1954-1972 (Abingdon, 2007).

Gold, John. 'A SPUR to action?: the Society for the Promotion of Urban Renewal, “anti-scatter" and the crisis of city reconstruction, 1957-1963', Planning Perspectives, 27:2 (2012), 199-233.

Goss, Anthony. 'Neighbourhood units in British new towns', Town Planning Review, 32:1 (1961), 66-82.

Greystone, Philip. The Blitz on Hull (1940-45) (York, 1991).

Grindrod, John. Concreteopia: A Journey around the Rebuilding of Post-war Britain (Brecon, 2013).

Gunn, Simon. 'The rise and fall of British urban modernism: planning Bradford, circa 1945-1970', Journal of British Studies, 49:4 (2010), 849-69.

Gunn, Simon. 'The Buchanan Report, environment and the problem of traffic in 1960s Britain', Twentieth Century British History, 22:4 (2011), 521-42.

Gunn, Simon. 'European urbanities since 1945: a commentary', Contemporary European History, 24:4 (2015), 617-22.

Gunn, Simon, and Robert J. Morris (eds). Identities in Space: Contested Terrains in the Western City since 1850 (Aldershot, 2001).

Gunn, Simon, and James Vernon (eds). The Peculiarities of Liberal Modernity in Imperial Britain (London, 2011).

Guy, Cliff. 'Corporate strategies in food retailing and their local impacts: a case study of Cardiff', Environment and Planning A, 28:9 (1996), 1575-602.

Hall, Peter. London 2000 (London, 1963).

Hall, Peter. Urban and Regional Planning (London, 1992).

Hall, Peter. Cities of Tomorrow: An Intellectual History of Urban Planning and Design in the Twentieth Century (Oxford, 1996).

Halsey, A.H. (ed.). Trends in British Society since 1900 (London, 1972).

Hanley, Lyndsey. Estates: An Intimate History (London, 2012).

Harris, Richard, and Peter J. Larkham (eds). Changing Suburbs: Foundation, Form, and Function (London, 1999).

Hartwell, Clare. Manchester (London, 2002).

Harvey, David. The Urbanization of Capital: Studies in the History and Theory of Capitalist Urbanization (Baltimore, 1985).

Hasegawa, Junichi. Replanning the Blitzed City Centre: A Comparative Study of Bristol, Coventry and Southampton (Buckingham, 1992). 
Hasegawa, Junichi. 'Governments, consultants and expert bodies in the physical reconstruction of the city of London in the 1940s', Planning Perspectives, 14: 2 (1999), 121-44.

Hasegawa, Junichi. 'The rise and fall of radical reconstruction in 1940s Britain', Twentieth Century British History, 10:2 (1999), 137-61.

Hasegawa, Junichi. 'Reconstruction of Portsmouth in the 1940s', Contemporary British History, 14:1 (2000), 45-62.

Hatherley, Owen. Militant Modernism (Hampshire, 2008).

Hayden, Dolores. The Power of Place: Urban Landscapes as Public History (London, 1995).

Hayes, Nick. Consensus and Controversy: City Politics in Nottingham 1945-66 (Liverpool, 1996).

Healey, Dan. 'Masculine purity and "gentlemen's mischief": sexual exchange and prostitution between Russian men, 1861-1941', Slavic Review, 60:2 (2001), 233-65.

Hewitt, Kenneth. 'Place annihilation: area bombing and the fate of urban places', Annals of the Association of American Geographers, 73:2 (1983), 257-84.

Hewitt, Kenneth. "“When the great planes came and made ashes of our city ...”: towards an oral geography of the disasters of war', Antipode, 26:1 (1994), $1-34$.

Hilton, Matthew. Consumerism in Twentieth-century Britain: The Search for a Historical Movement (Cambridge, 2003).

Hinton, James. '1945 and the apathy school', History Workshop Journal, 43 (1997), 267-73.

Hoggart, Richard. The Uses of Literacy: Aspects of Working-class Life, with Special References to Publications and Entertainments (London, 1971).

Hollow, Matthew. 'Utopian urges: visions for reconstruction in Britain, 19401950', Planning Perspectives, 27:4 (2012), 569-85.

Homer, Andrew. 'Creating new communities: the role of the neighbourhood unit in post-war British planning', Contemporary British History, 14:1 (2000), 63-80.

Houlbrook, Matt. Queer London: Perils and Pleasures in the Sexual Metropolis, 1918-1957 (London, 2005).

Houlbrook, Matt. 'The man with the powder puff in interwar London', Historical Journal, 50:1 (2007), 145-71.

Howard, Ebenezer. Garden Cities of To-morrow (Eastbourne, 1985 [1898]).

Hubbard, Phil, Lucy Faire, and Keith Lilley. 'Contesting the modern city: reconstruction and everyday life in post-war Coventry', Planning Perspectives, 18:4 (2003), 377-97.

Jacobs, Jane. The Death and Life of Great American Cities (New York, 1961).

Jefferys, James B. Retail Trading in Britain 1850-1950 (Cambridge, 1954).

Jerram, Leif. Germany's Other Modernity: Munich and the Making of Metropolis, 1895-1930 (Manchester, 2007). 
Jerram, Leif. Streetlife: The Untold History of Europe's Twentieth Century (Oxford, 2011).

Jerram, Leif. 'Space: a useless category of historical analysis?', History and Theory, 52:2 (2013), 400-19.

Johnson, Donald Leslie. 'Origin of the neighbourhood unit', Planning Perspectives, 17:3 (2002), 227-45.

Johnstone, Craig, and Mark Whitehead (eds). New Horizons in British Urban Policy: Perspectives on New Labour's Urban Renaissance (Aldershot, 2004).

Jones, Ben. 'The uses of nostalgia: autobiography, community publishing and working class neighbourhoods in post-war England', Cultural and Social History, 7:3 (2010), 355-74.

Jones, Gareth Stedman. Outcast London: A Study in the Relationship between Classes in Victorian Society (Harmondsworth, 1984).

Jones, Harriet. "“This is magnificent!": 300,000 houses a year and the Tory revival after 1945', Contemporary British History, 14:1 (2000), 99-121.

Jones, Phil. 'Historical continuity and post-1945 urban redevelopment: the example of Lee Bank, Birmingham, UK', Planning Perspectives, 19:4 (2004), 365-89.

Jones, Philip N. ““...A fairer and nobler city” - Lutyens and Abercrombie's Plan for the city of Hull 1945', Planning Perspectives, 13:1 (1998), 301-16.

Joyce, Patrick. The Rule of Freedom: Liberalism and the Modern City (London, 2003).

Kargon, Robert. Science in Victorian Manchester (Manchester, 1978).

Keating, Dennis, and Norman Krumholz. 'Neighborhood planning', Journal of Planning Education and Research, 20:1 (2000), 111-4.

Kefford, Alistair. 'Planning for affluence: consumption and citizenship on the Seacroft estate, Leeds', paper given at Centre for Urban History conference, 'The Transformation of Urban Britain since 1945', University of Leicester, July 2013.

Kefford, Alistair. 'Disruption, destruction and the creation of "the inner cities": the impact of urban renewal on industry, 1945-80', Twentieth Century British History (forthcoming).

Kershaw, Ian. The Nazi Dictatorship: Problems and Perspectives of Interpretation (London, 2000).

Kidd, Alan J. Manchester: A History (Lancaster, 2006).

Kidd, Alan J., and Kenneth Roberts (eds). City, Class and Culture: Studies of Social Policy and Cultural Production in Victorian Manchester (Manchester, 1985).

Kitchen, Ted. 'The future of development plans: reflections on Manchester's experiences 1945-1995', Town Planning Review, 67:3 (1996), 331-53.

Kitchin, Robert, and Martin Dodge. 'Rethinking maps', Progress in Human Geography, 33:3 (2007), 1-14.

Klemek, Christopher. The Transatlantic Collapse of Urban Renewal (Chicago, 2011). 
Kruse, Kevin M., and Thomas J. Sugrue (eds), The New Suburban History (Chicago, 2006).

Kynaston, David. Austerity Britain, 1945-1951 (London, 2007).

Lang, Jon. Creating Architectural Theory: The Role of the Behavioural Sciences in Environmental Design (New York, 1987).

Langhamer, Claire. 'The meanings of home in postwar Britain', Journal of Contemporary History, 40:2 (2005), 341-62.

Larkham, Peter J. 'Rebuilding the industrial town: wartime Wolverhampton', Urban History, 29:3 (2002), 388-409.

Larkham, Peter J. 'The place of urban conservation in the UK reconstruction plans of 1942-1952', Planning Perspectives, 18:3 (2003), 295-324.

Larkham, Peter J. 'People, planning and place: the roles of client and consultants in reconstructing postwar Bilston and Dudley', Town Planning Review, 77:5 (2006), 557-82.

Larkham, Peter J. 'Thomas Sharp and the post-war replanning of Chichester: conflict, confusion and delay', Planning Perspectives, 24:1 (2009), 51-75.

Larkham, Peter J. 'Hostages to history? The surprising survival of critical comments about British planning and planners c. 1942-1955, Planning Perspectives, 26:3 (2012), 487-91.

Larkham, Peter J., and Keith Lilley. Planning the 'City of Tomorrow': British Reconstruction Planning, 1939-1952: An Annotated Bibliography (Pickering, 2001).

Larkham, Peter J., and Keith Lilley. 'Plans, planners and city images: place promotion and civic boosterism in British reconstruction planning', Urban History, 30:2 (2003), 183-205.

Larkham, Peter J., and John Pendlebury. 'Reconstruction planning and the small town in early post-war Britain', Planning Perspectives, 23:3 (2008), 291-321.

Latour, Bruno. Science in Action: How to Follow Scientists and Engineers through Society (Cambridge, MA, 1987).

Laulajainen, Risto, and Lars-Erik Gadde. 'Locational avoidance: a case study of three Swedish retail chains', Regional Studies, 20:2 (1986), 131-40.

Lawhon, Larry Lloyd. 'The neighborhood unit: physical design or physical determinism?', Journal of Planning History, 8:2 (2009), 111-32.

Lee, Terence. 'Urban neighbourhood as a socio-spatial schema', Human Relations, 21:3 (1968), 241-67.

Lefebvre, Henri. The Production of Space, trans. Donald Nicholson-Smith (Oxford, 1991).

Lewis, Alan. 'Planning through conflict: the genesis of Sheffield's post-war reconstruction plan', Planning Perspectives, 24:3 (2009), 381-3.

Lewis, Alan. 'A history of Sheffield's central area planning schemes, 1936-1952' (Unpublished PhD thesis, University of Sheffield, 2006).

Lilla, Mark. The Reckless Mind: Intellectuals in Politics (New York, 2001).

Lowe, Michelle S. 'Britain's regional shopping centres: new urban forms?', Urban Studies, 37:2 (2000), 261-74. 
Macleod, Gordon, and Mark Goodwin. 'Space, scale and state strategy: rethinking urban and regional governance', Progress in Human Geography, 23:4 (1999), 503-27.

Malpass, Peter, and Alan Murie. Housing Policy and Practice (Basingstoke, 1994).

Manchester City Council, Manchester: 50 Years of Change: Post-war Planning in Manchester (London, 1995).

Mann, Peter H. 'The concept of neighborliness', American Journal of Sociology, 60:2 (1954), 163-8.

Marmaras, Emmanuel, and Anthony Sutcliffe. 'Planning for post-war London: the three independent plans, 1942-3', Planning Perspectives, 9:4 (1994), 431-53.

Marriott, Oliver. The Property Boom (London, 1967).

Massey, Doreen. Space, Place and Gender (Cambridge, 1994).

Mattocks, Robert Henry. 'Report of the Manchester and District Joint Town Planning Advisory Committee', Town Planning Review, 12:3 (1927), 226-8.

McCulloch, F.J. 'Research and planning', Town Planning Review, 23:1 (1952), 26-39.

McKibbin, Ross. Classes and Cultures: England, 1918-1951 (Oxford, 1998).

Meller, Helen. 'Urban renewal and citizenship: the quality of life in British cities, 1890-1990', Urban History, 22:1 (1995), 63-84.

Mellor, Leo. Reading the Ruins: Modernism, Bombsites and British Culture (Cambridge, 2011).

Merrifield, Andy. 'The dialectics of dystopia: disorder and zero tolerance in the city', International Journal of Urban and Regional Research, 24:2 (2001), 473-89.

Mitchell, Don. 'The end of public space? People's Park, definitions of the public, and democracy', Annals of the Association of American Geographers, 85:1 (1995), 108-33.

Mogey, John M. Family and Neighbourhood: Two Studies of Oxford (Oxford, 1956).

Mort, Frank. 'Fantasies of metropolitan life: planning London in the 1940s', Journal of British Studies, 43:1 (2004), 120-51.

Mort, Frank. 'Scandalous events: metropolitan culture and moral change in post-Second World War London', Representations, 93:1 (2006), 106-37.

Mumford, Eric. The CIAM Discourse on Urbanisms, 1929-1960 (Cambridge, MA, 2002).

Nead, Lynda. Victorian Babylon: People, Streets and Images in Nineteenthcentury London (London, 2000).

Neave, David, and Susan Neave. Hull (London, 2012).

Nevell, Michael. Manchester: The Hidden History (Stroud, 2008).

Newby, Howard. The Deferential Worker: A Study of Farm Workers in East Anglia (London, 1977).

Newby, Peter. 'Shopping as leisure', in Rosemary Bromley and Colin Thomas (eds), Retail Change: Contemporary Issues (London, 1993), pp. 208-28. 
Newman, Oscar. Defensible Space: People and Design in the Violent City (London, 1973).

Olechnowicz, Andrzej, Working-class Housing in England between the Wars: The Becontree Estate (Oxford, 1997).

Ortolano, Guy. 'Planning the urban future in 1960s Britain', Historical Journal, 54:2 (2011), 477-507.

Osgerby, Bill. Youth in Britain since 1945 (Oxford, 1998).

Otter, Chris. 'Making Liberalism durable: vision and civility in the late Victorian city', Social History, 27:1 (2002), 1-15.

Owens, Patsy Eubanks. 'No teens allowed: the exclusion of adolescents from public spaces', Landscape Journal, 21:1 (2002), 156-63.

Patricios, Nicholas. 'The neighborhood concept: a retrospective of physical design and social interaction', Journal of Architectural and Planning Research, 19:1 (2002), 70-90.

Pahl, R.E. (ed.). Readings in Urban Sociology (Oxford, 1968).

Pearson, Geoffrey. Hooligan: A History of Respectable Fears (London, 1983).

Pendlebury, John. 'Alas Smith and Burns? Conservation in Newcastle upon Tyne city centre, 1959-1968', Planning Perspectives, 16:2 (2001), 115-41.

Pendlebury, John. 'Planning the historic city: reconstruction plans in the United Kingdom in the 1940s', Town Planning Review, 74:4 (2003), 371-93.

Pendlebury, John. 'Reconciling history with modernity: 1940s plans for Durham and Warwick', Environment and Planning B: Planning and Design, 31:3 (2004), 331-48.

Perkins, Chris, and Martin Dodge. 'Mapping the imagined future: the roles of visual representation in the 1945 City of Manchester Plan', Bulletin of the Jobn Rylands Library, 89:1 (2012), 247-76.

Perry, Clarence Arthur. The Neighbourhood Unit (London 1998 [1929]).

Peukert, Detlev. The Weimar Republic: The Crisis of Classical Modernity, trans. Richard Deveson (London, 1991).

Philo, Chris. A Geographical History of Institutional Provision for the Insane from Medieval Times to the 1860s in England and Wales (Lampeter, 2004).

Pickett, Brent L. 'Foucault and the politics of resistance', Polity, 28:4 (1996), 445-66.

Pile, Steve, and Michael Keith (eds). Geographies of Resistance (London, 1997).

Platt, Harold L. Shock Cities: The Environmental Transformation and Reform of Manchester and Chicago (Chicago, 2005).

Pooley, Colin G., and Sandra Irish. 'Access to housing on Merseyside, 1919-39', Transactions of the Institute of British Geographers, New Series, 12:2 (1987), 177-90.

Porter, Roy (ed.). Rewriting the Self: Histories from the Renaissance to the Present (London, 1997).

Power, Anne. Property before People: The Management of Twentieth Century Council Housing (London, 1987).

Power, Anne. Hovels to High Rise: State Housing in Europe since 1850 (London, 1993). 
Power, Anne. Estates on the Edge: The Social Consequences of Mass Housing in Northern Europe (Basingstoke, 1997).

Power, Anne. 'High-rise estates in Europe: is rescue possible?', Journal of European Social Policy, 9:2 (1999), 139-63.

Pred, Allan. 'Place as historically contingent process: structuration and the time-geography of becoming places', Annals of the Association of American Geographers, 74:2 (1984), 279-97.

Raco, Mike. 'Remaking place and securitising space: urban regeneration and the strategies, tactics and practices of policing in the UK', Urban Studies, 40:9 (2003), 1869-87.

Ravetz, Alison. Remaking Cities (London, 1980).

Ravetz, Alison. The Government of Space: Town Planning in Modern Society (London, 1986).

Ravetz, Alison. Council Housing and Culture: The History of a Social Experiment (London, 2001).

Ray, John. The Night Blitz: 1940-1941 (London, 1996).

Relph, Edward. Place and Placelessness (London, 1976).

Robertson, Douglas, Ian McIntosh, and James Smyth. 'Neighbourhood identity: the path dependency of class and place', Housing, Theory and Society, 27:3 (2010), 258-73.

Rose, Nikolas. Governing the Soul: The Shaping of the Private Self (London, 1990).

Rose, Nikolas. Powers of Freedom: Reframing Political Thought (Cambridge, 1999).

Rose, Sonia O. Which People's War? National Identity and Citizenship in Wartime Britain (Oxford, 2004).

Routledge, Paul. Terrains of Resistance: Nonviolent Social Movements and the Contestation of Place in India (Westport, 1993).

Rycroft, Simon, and Denis Cosgrove, 'Mapping the modern nation: Dudley Stamp and the land utilisation survey', History Workshop Journal, 40 (1995), 91-105.

Saumarez Smith, Otto. 'Central government and town centre redevelopment, 1959-1966', Historical Journal, 58:1 (2015), 217-44.

Scott, James C. Seeing Like a State (London, 2000).

Seamon, David A. Geography of the Lifeworld: Movement, Rest and Encounter (London, 1979).

Seamon, David A., and Anne Buttimer (eds). The Human Experience of Space and Place (London, 1980).

Shapely, Peter. Charity and Power in Victorian Manchester (Manchester, 2000).

Shapely, Peter, Duncan Tanner, and Andrew Walling. 'Civic culture and housing policy in Manchester, 1945-79', Twentieth Century British History, 15:4 (2004), 410-34.

Sharp, Thomas. Town Planning (London, 1940).

Shaw, Gareth. Processes and Patterns in the Geography of Retail Change, with Special Reference to Kingston upon Hull, 1880-1950 (Hull, 1978). 
Shaw, Gareth, Louise Curth, and Andrew Alexander. 'Selling self-service and the supermarket: the Americanisation of food retailing in Britain, 1945-60', Business History, 46:4 (2004), 568-82.

Sheldrake, John. Municipal Socialism (Avebury, 1989).

Short, John R. Housing in Britain: The Post-war Experience (London, 1982).

Silkin, Lewis. 'Housing layout in theory and practice', Journal of the Royal Institute of British Architects, 55:10 (1948), 431-2.

Silver, Christopher. 'Neighborhood planning in historical perspective', Journal of the American Planning Association, 51:2 (1985), 161-74.

Simmel, Georg. Simmel on Culture: Selected Writings, David Frisby and Mike Featherstone (eds) (London, 1997).

Simon, Ernest Darwin, and John Inman. The Rebuilding of Manchester (London, 1935).

Simon, Alfred P. Manchester Made Over (London, 1936).

Smith, Harold L. (ed.). War and Social Change: British Society since the Second World War (Manchester, 1986).

Smith, Peter J.C., and Neil Richardson. Luftwaffe over Manchester: The Blitz Years 1940-1944 (Radcliffe, 2003).

Soja, Edward. Thirdspace: Journeys to Los Angeles and Other Real-andImagined Places (Oxford, 1996).

Stevenson, Greg. Palaces for the People: Prefabs in Post-war Britain (London, 2003).

Stevenson, John. British Society 1914-45 (London, 1984).

Stewart, Murray. The City: The Problems of Planning (Harmondsworth, 1972). Sullivan, John. 'Local government in decline?', Fabian Quarterly, 28 (1940), 12-29.

Talen, Emily. 'Do plans get implemented? A review of evaluation in planning', Journal of Planning Literature, 10:3 (1996), 248-59.

Tallon, Andrew. Urban Regeneration in the UK (London, 2013).

Thorns, David. The Transformation of Cities: Urban Theory and Urban Life (Basingstoke, 2002).

Tichelar, Michael. 'Central local tensions: the case of the Labour Party, regional government and land-use reform during the Second World War', Labour History Review, 66:2 (2001), 187-206.

Tichelar, Michael. 'The conflict over property rights during the Second World War: the Labour Party's abandonment of land nationalization', Twentieth Century British History, 14:2 (2003), 165-88.

Tilly, Charles. 'Spaces of contention', Mobilization, 5:2 (2000), 135-59.

Tilly, Charles. 'Contention over space and place', Mobilization, 8:2 (2003), 221-5.

Tiratsoo, Nick. Reconstruction, Affluence and Labour Politics: Coventry, 19451960 (London, 1990).

Tiratsoo, Nick. The Attlee Years (London, 1991).

Tiratsoo, Nick. 'The reconstruction of blitzed British cities, 1945-55: myths and reality', Contemporary British History, 14:1 (2000), 27-44. 
Tiratsoo, Nick, Junichi Hasegawa, Tony Mason, and Takao Matsumura. Urban Reconstruction in Britain and Japan 1945-1955: Dreams, Plans and Realities (Luton, 2000).

Todd, Selina. 'Poverty and aspiration: young women's entry to employment in inter-war England', Twentieth Century British History, 15:2 (2004), 119-42.

Tönnies, Ferdinand. Tönnies: Community and Civil Society, José Harris (ed.), trans. Margaret Hollis (Cambridge, 2001).

Tuan, Yi-Fu, Place and Space: The Perspective of Experience (London, 1977).

Turner, Victor Witter. The Ritual Process: Structure and Anti-structure (London, 1969).

Unwin, Raymond. Town Planning in Practice: An Introduction to the Art of Designing Cities and Suburbs (Princeton, 1996 [1909]).

Urry, John. Consuming Places (London, 1995).

Vale, Brenda. Prefabs: A History of the UK Temporary Housing Programme (London, 1995).

Vansittart, Robert. Black Record: Germans Past and Present (London, 1941).

Vertesi, Janet. 'Mind the gap: the London Underground map and users' representations of urban space', Social Studies of Science, 38:1 (2008), 7-33.

Viola, Lynne. 'Popular resistance in the Stalinist 1930s: soliloquy of a devil's advocate', Kritika, 1:1 (2000), 45-69.

Walter, Marianne. 'The housing estate: a warning', Contemporary Review, May (1945), 285-90.

Ward, Stephen. Planning and Urban Change (London, 2004).

Warf, Barney, and Santa Arias (eds). The Spatial Turn: Interdisciplinary Perspectives (New York, 2009).

Watt, Donald. Britain Looks to Germany: British Opinion and Policy towards Germany since 1945 (London, 1965).

Weber, Max. The Protestant Ethic and the Spirit of Capitalism, trans. Talcott Parsons (London, 1930).

Weiler, Peter. 'The rise and fall of the Conservatives' "grand design for housing", 1951-64', Contemporary British History, 14:1 (2000), 122-50.

White, Jerry. London in the Twentieth Century: A City and Its People (London, 2008).

Whyte, Iain Boyd (ed.). Man-made Future: Planning, Education and Design in Mid-twentieth-century Britain (London, 2007).

Whyte, William. 'The Englishness of English architecture: modernism and the making of a national international style, 1927-1957', Journal of British Studies, 48:2 (2009), 441-65.

Wild, M.T., and Gareth Shaw, 'Locational behaviour of urban retailing during the nineteenth century: the example of Kingston upon Hull', Transactions of the Institute of British Geographers, 61 (1974), 101-18.

Wildman, Charlotte. Urban Redevelopment and Modernity in Liverpool and Manchester, 1918-1939 (London, 2016).

Williams, Raymond, and Tony Pinkney. The Politics of Modernism: Against the New Conformists (London, 1989). 
Willmott, Peter. 'Housing density and town design in a new town', Town Planning Review, 33:2 (1962), 115-27.

Willmott, Peter. 'Social research and new communities', Journal of the American Institute of Planners, 33:6 (1967), 387-98.

Willmott, Peter. Community Initiatives: Patterns and Prospects (London, 1989).

Wilson, Penny. 'Beyond the gaudy fence', International Journal of Play, 1:1 (2012), 30-6.

Wittrock, Bjorn. 'Modernity: one, none, or many? European origins and modernity as a global condition', Daedalus, 129:1 (2000), 31-60.

Wood, Christopher. Geography of Pollution: Study of Greater Manchester (Manchester, 1973).

Wood, Christopher, and Nicholas Pendleton. Land Use Planning and Pollution Control in Practice (Manchester, 1979).

Wrigley, Neil, Cliff Guy, and Michelle Lowe. 'Urban regeneration, social inclusion and large store development: the Seacroft development in context', Urban Studies, 39:11 (2002), 2101-14.

Wyke, Terry. A Hall for All Seasons: A History of the Free Trade Hall (Manchester, 1996).

Yeoh, Brenda S. Contesting Space in Colonial Singapore: Power Relations and the Urban Built Environment (Singapore, 2003).

Young, Ken, and Nirmala Rao. Local Government since 1945 (Oxford, 1997).

Young, Terence. Becontree and Dagenham: A Report Made for the Pilgrim Trust (Becontree, 1934).

Zukin, Sharon. The Cultures of Cities (Oxford, 1995).

Zweiniger-Bargielowska, Ina. 'Rationing austerity and the Conservative Party recovery after 1945', Historical Journal, 37:1 (1994), 173-97.

Zweiniger-Bargielowska, Ina. Austerity in Britain: Rationing, Controls, and Consumption, 1939-1955 (Oxford, 2000). 